\title{
Stabilization of Self-slaking Slags from Ferroalloy Production
}

\section{Alexander Vladimirovich Sychev, Vladimir Ivanovich Zhuchkov, and Oleg Vadimovich Zayakin}

Institute of Metallurgy, Ural Branch of the Russian Academy of Sciences, Yekaterinburg, Russia

\section{Abstract}

In this study, the process of stabilization for highly basic self-slaking slags of ferroalloy production by various boron-containing materials were studied: tincalconite, colemanite, and ulexite (produced in Turkey). The viscosities and temperatures of crystallization for the initial boron-containing materials are determined. Under laboratory conditions, high-base slag melts were treated with boron-containing materials to obtain slags containing 0.25 and $0.5 \% \mathrm{~B}_{2} \mathrm{O}_{3}$. It was shown that the addition of boric anhydride to the studied slag melts extends the homogeneous-liquid state interval and reduces their viscosity by 1.2-1.6 times, therefore $\mathrm{B}_{2} \mathrm{O}_{3}$ can be used as a tool for controlling

Corresponding Author: Oleg Vadimovich Zayakin zferro@mail.ru

Received: 5 February 2019 Accepted: 6 March 2019 Published: 17 March 2019 Publishing services provided by Knowledge E

(c) Alexander Vladimirovich Sychev et al. This article is distributed under the terms of the Creative Commons

Attribution License, which permits unrestricted use and redistribution provided that the original author and source are credited.

Selection and Peer-review under the responsibility of the NIOKR-2018 Conference Committee.

\section{G OPEN ACCESS} slag mobility in industrial conditions. The industrial tests were conducted to stabilize the slag of low-carbon ferrochrome using powdered calcined, briquetted, and fused colemanite. After treatment, slags contained $43-47 \% \mathrm{CaO}, 0.18-0.45 \% \mathrm{~B}_{2} \mathrm{O}_{3}$. The results of pilot-industrial experiments show that all applied boron-containing materials ensure slag stabilization and differ only in the degree of boron recovery. Fused colemanite showed the highest results in the recovery of $\mathrm{B}_{2} \mathrm{O}_{3}$ (up to 98\%), a commercial product was obtained which fully complies according to the technical characteristics with the requirements of Specification TU 0798-69-00186499-2014 "Crushed stone and sand from ferroalloy slags. Technical conditions."

Keywords: ferroalloy, slag, self-slaking slag, stabilization, boron, two-calcium silicate

\section{Introduction}

The production process for refined grades of ferromanganese and ferrochrome can be carried out both in an electric furnace and outside of it by the method of mixing in special ladles. Both methods are implemented at industrial enterprises of different countries, have both their advantages and disadvantages, and the choice of each of them is determined by the quality of the used ore materials, lime, reductant, the availability of appropriate capacities and the required quality of the final product. It is also known that both methods have one common disadvantage, the solution of which will allow increasing the efficiency of the smelting process for low- and medium-carbon 
ferromanganese and ferrochrome. This is the process of self-slaking of highly basic slags (with basicity $\left(\mathrm{CaO} / \mathrm{SiO}_{2}\right)$ more than 1.4) into a fine powder. At the same time, only a small part of such slag is used in industry or agriculture, and the main part (millions of tons) is accumulated in dumps, representing a serious environmental hazard. Both Russian [1-4] and foreign [5-7] specialists are engaged in the problem of stabilizing self- slaking slags in the ferrous metallurgy. In recent years, the volume of generated slags has significantly increased due to the forced transition to the use of poor types of mineral raw materials [8-10]. The issues of studying the processes of slaking of such slags, identifying the causes and eliminating their self-dispersion are very relevant in modern conditions.

Typically, the slags of refined ferrochrome (SRFC) contain, \%: \%: $\mathrm{CaO} 47-52 ; \mathrm{SiO}_{2} 24-31$;

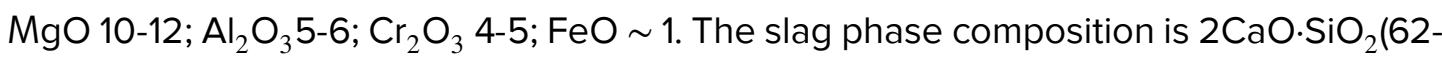

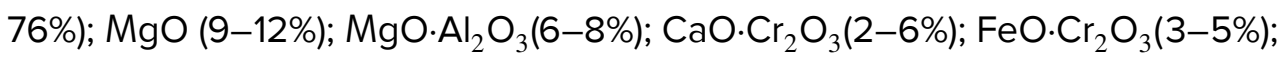

$3 \mathrm{Cr}_{2} \mathrm{O}_{3} \cdot \mathrm{MgO} \cdot 2 \mathrm{SiO}_{2}$ (up to $13 \%$ ) [11]. The majority of slaking slag consists of $\mathrm{Y}-$ $\mathrm{Ca}_{2} \cdot \mathrm{SiO}_{4}$, and non- slaking of $\beta-\mathrm{Ca}_{2} \cdot \mathrm{SiO}_{4}$.

The main parameters for preventing the transition of $\beta-\mathrm{Ca}_{2} \cdot \mathrm{SiO}_{4}$ to $\gamma-\mathrm{Ca}_{2} \cdot \mathrm{SiO}_{4}$ and the stabilization of the SRFC are: 1) slag hardening; 2 ) replacement of the calcium cation in $2 \mathrm{CaO} . \mathrm{SiO}_{2}$, for example, with a magnesium cation with the formation of ternary $\left(3 \mathrm{CaO} . \mathrm{MgO} .2 \mathrm{SiO}_{2}\right)$ or double $\left(2 \mathrm{MgO} . \mathrm{SiO}_{2}\right)$ non- slaking compounds; 3$)$ the formation of solid solutions of dicalcium silicate or the replacement of the $\mathrm{SiO}_{4}^{4-}$ anion of dicalcium silicate with other anions, for example, $\mathrm{PO}_{4}^{3-}, \mathrm{BO}_{4}^{5-}$ by introducing phosphates or borates. In this work, we studied the properties of stabilized slags by introduction of boroncontaining oxide materials.

The authors of [12-16] studied the complex of physicochemical properties for boron - containing oxide systems. The features of the technology for using various boroncontaining raw materials for the stabilization of disintegrating slags are noted. Using phase diagrams and their mathematical models, it was shown that the introduction of boric anhydride $\left(\mathrm{B}_{2} \mathrm{O}_{3}\right)$ influences the thermodynamics of metal production processes due to the formation of favorable for the technology minerals in the processed charge and the resulting slags. The influence of $\mathrm{B}_{2} \mathrm{O}_{3}$ on the viscosity and crystallization temperature of metallurgical slags, stabilization from slaking, which follows from the analysis of the diagrams constructed by the authors, turned out to be noticeable.

The viscosity and crystallization interval of the slag affect the extraction of chromium (precipitation of metal beads), the time that the slag spends in the liquid state and the contacting of the melt with stabilizer materials that affect the efficiency of the slag slaking effect elimination. In this regard, the viscosity of the SRFC with additives of 0.25 and $0.5 \%$ $\mathrm{B}_{2} \mathrm{O}_{3}$ and without additives was studied (Table 1). 
Experiments to determine the viscosity and temperature of slag crystallization were carried out on an electro vibration viscometer [17] in a Tamman furnace in molybdenum crucibles. The crystallization temperature of slags $\left(t_{c r}\right)$ was determined from the fracture of the line on the graph $\mathrm{Ln} \eta-\frac{1}{\eta}$, (viscosity - inverse temperature).

TABLE 1: Composition and crystallization temperature of the studied slags.

\begin{tabular}{|l|l|l|l|l|l|l|l|l|l|}
\hline $\mathbf{N}$ & \multicolumn{7}{|c}{ Composition, \% } & & \\
\hline & $\mathbf{C a O}$ & $\mathbf{S i O}_{2}$ & $\mathbf{M g O}$ & $\mathbf{A l}_{2} \mathbf{O}_{3}$ & $\mathbf{C r}_{2} \mathbf{O}_{3}$ & $\mathbf{F e O}$ & $\mathbf{B}_{2} \mathbf{O}_{3}$ & \\
\hline 1 & 46.74 & 31.16 & 10.76 & 5.82 & 4.25 & 1.27 & 0 & 1.5 & 1647 \\
\hline 2 & 46.62 & 31.08 & 10.73 & 5.81 & 4.24 & 1.27 & 0.25 & 1.5 & 1634 \\
\hline 3 & 48.52 & 28.54 & 11.17 & 6.04 & 4.41 & 1.32 & 0 & 1.7 & 1725 \\
\hline 4 & 48.40 & 28.47 & 11.14 & 6.02 & 4.40 & 1.32 & 0.25 & 1.7 & 1711 \\
\hline 5 & 48.28 & 28.40 & 11.11 & 6.01 & 4.39 & 1.31 & 0.5 & 1.7 & 1706 \\
\hline 6 & 50.29 & 26.47 & 11.31 & 6.12 & 4.47 & 1.34 & 0 & 1.9 & 1739 \\
\hline 7 & 50.16 & 26.40 & 11.29 & 6.10 & 4.46 & 1.34 & 0.25 & 1.9 & 1726 \\
\hline 8 & 50.04 & 26.34 & 11.25 & 6.09 & 4.45 & 1.33 & 0.5 & 1.9 & 1722 \\
\hline 9 & 52.79 & 25.14 & 10.74 & 5.81 & 4.24 & 1.28 & 0 & 2.1 & 1764 \\
\hline 10 & 52.66 & 25.08 & 10.70 & 5.80 & 4.23 & 1.28 & 0.25 & 2.1 & 1749 \\
\hline
\end{tabular}

From the obtained results, it follows that slags, specific for the production conditions, with 1.7-2.1 basicity are refractory, falling slags, solidifying in a narrow temperature range. When melted, these slags have a low viscosity.

At a temperature of $1750^{\circ} \mathrm{C}$, almost all slags (except sample 9, table 1) have a high mobility (viscosity $0.09-0.22 \mathrm{~Pa} \cdot \mathrm{s}$ ). Slag 9 with basicity 2.1 enters the specified viscosity range only if the melt contains $0.25 \% \mathrm{~B}_{2} \mathrm{O}_{3}(0.17 \mathrm{~Pa} \cdot \mathrm{s})$ or the temperature rises to 1780 $1790^{\circ} \mathrm{C}(0.12 \mathrm{~Pa} \mathrm{~s})$.

When cooling melts to a temperature of $1700^{\circ} \mathrm{C}$, highly basic slags, regardless of the $\mathrm{B}_{2} \mathrm{O}_{3}$ concentration, become dry slag (viscosity 0.8-1.0 Pa $\cdot \mathrm{s}$ or more). Only slags of lower basicity -1.5 (boron and non-boron) and 1.7 (with $0.5 \% \mathrm{~B}_{2} \mathrm{O}_{3}$ ) have fluidity sufficient for practice $(0.09-0.33 \mathrm{~Pa} \cdot \mathrm{s})$. In general, the addition of boric anhydride to the slag melts reduces their viscosity by $1.2-1.6$ times, which can be used as a tool for controlling their fluidity.

The presence of $\mathrm{B}_{2} \mathrm{O}_{3}$ in the slags expands the range of the homogeneous liquid state, reducing the temperature of the crystallization onset.

Thus, the presence of $0.25-0.50 \% \mathrm{~B}_{2} \mathrm{O}_{3}$ in slags makes them fluid and stable over a wide range of temperatures, which should have a positive effect on the melting and on the loss of metal with slags. 
Due to the fact that the type of boron-containing materials is of great importance during stabilization, studies have been conducted to learn the properties and selection of stabilizer materials. The boron-containing materials of "Etiproducts" (Turkey) were investigated.

The results of chemical analysis and the temperature of crystallization start $\left(\mathrm{t}_{s . c r}\right)$ for boron-containing materials are presented in table 2 .

TABLE 2: Chemical composition and temperatures of the crystallization start for boron-containing materials.

Material
Tincalconite
Colemanite
Ulexite

\begin{tabular}{|l|c|c|c|c|c|c|c|c|}
\hline \multicolumn{8}{|c|}{ Composition, \% } & $\mathbf{T}_{\text {s.cr.. }}{ }^{o} \mathbf{C}$ \\
\hline $\mathbf{B}_{2} \mathbf{O}_{3}$ & $\mathbf{C a O}$ & $\mathbf{M g O}$ & $\mathbf{S i O}_{2}$ & $\mathbf{A l}_{2} \mathbf{O}_{3}$ & $\mathbf{N a}_{2} \mathbf{O}$ & Loss on ignition & \\
\hline 43.82 & 5.4 & 5.85 & 3.63 & - & 14.3 & 24.5 & 863 \\
\hline 38.78 & 27.9 & 3.6 & 5.63 & 0.69 & - & 23.37 & 1004 \\
\hline 35.98 & 18.9 & 4.95 & 4.95 & 0.23 & 5.52 & 33.62 & 940 \\
\hline
\end{tabular}

Studies assessing the behavior of boron-containing materials in the process from heating to melting have shown that colemanite in the process of heating up to the melting temperature passes through the stage of disintegration into a fine powder with an almost twofold increase in volume. This process is accompanied by the cracking of lumpy ore and, as a consequence, the release of both dust and lumpy ore from the smelting unit. The process of tincalconite melting is accompanied by a strong bloating of the resulting viscous slag-foam mass. The intensity of this process is directly proportional to the heating rate of the material. Unlike tincalconite, the melting of ulexite proceeds calmly without emissions and changes in the particle size distribution.

A study of the viscosity for boron-containing raw materials in the temperature range of 700-1200 ${ }^{\circ} \mathrm{C}$ showed that their viscosity does not exceed 0.1-0.2 Pa.s. The low viscosity and temperature of crystallization for the studied boron-containing materials makes them suitable for use as fluxing and slag-forming additives for smelting and ladle processing of ferrous and non-ferrous metals. However, for most processes of smelting ferrous metals and ferroalloys, the presence of alkali metal oxides is undesirable because of their negative impact on the lining durability and increased emissions, therefore the prospects for using sodium-containing tincalconite and ulexite are visible only in the non-ferrous metallurgy.

In this regard, further studies were carried out with burnt colemanite, which has a high content of $\mathrm{B}_{2} \mathrm{O}_{3}(\geq 40.0 \%)$, it lacks crystallization water and it can be prepared to the desired fractional composition.

Considering the loss of a significant amount of fine colemanite $(0.1-1.0 \mathrm{~mm})$ during transportation, reloading, and putting into the ladle before pouring liquid slag, the material requires briquetting or remelting. 
Laboratory and industrial briquetting of burnt colemanite was carried out without binder components and moistening. Tests of briquettes showed their satisfactory strength. The destruction of the samples occurred at a load of $35 \mathrm{~kg} /$ briquette, and at 3 times fall from a height of $1.5 \mathrm{~m}$ the briquettes were only partially cracked.

To study the effectiveness of various amounts of $\mathrm{B}_{2} \mathrm{O}_{3}$ (from colemanite) on the stabilization of the SRFC, laboratory experiments were carried out in the Tamman furnace. After melting, in slag was not introduced or introduced $0.1 ; 0.3$ and $0.5 \%$ of $\mathrm{B}_{2} \mathrm{O}_{3}$. Slags without $\mathrm{B}_{2} \mathrm{O}_{3}$ and with $0.1 \% \mathrm{~B}_{2} \mathrm{O}_{3}$ disintegrated, and with 0.3 and $0.5 \% \mathrm{~B}_{2} \mathrm{O}_{3}$ were stabilized.

Industrial tests for the stabilization of low-carbon ferrochrome slag were carried out at Serovsky Ferroalloy Plant OJSC ("SZF") using powder-like calcined colemanite (49\% $\left.\mathrm{B}_{2} \mathrm{O}_{3}\right)$, briquetted colemanite $\left(47.7 \% \mathrm{~B}_{2} \mathrm{O}_{3}\right)$ and fused colemanite $\left(42.8 \% \mathrm{~B}_{2} \mathrm{O}_{3}\right)$. Colemanite was loaded into the bowl into which slag was poured from the ladle. A total of 23 bowls of slag were processed.

Slags of low-carbon ferrochrome contained $43-47 \% \mathrm{CaO}, 0.18-0.45 \% \mathrm{~B}_{2} \mathrm{O}_{3}$. The results of experimental-industrial trials show that all applied boron-containing materials ensure their stabilization. At the same time, the recovery of $\mathrm{B}_{2} \mathrm{O}_{3}$ from various boron-containing materials was:

1. from powdered colemanite $63-64 \%$;

2. from briquetted colemanite $65-91 \%$;

3. from fused colemanite $>98 \%$.

Located at the slag dump of OJSC "SZF" slags treated with colemanite (containing more than $0.15 \%$ of $\mathrm{B}_{2} \mathrm{O}_{3}$ ) based on the results of observations retain a state stable to self-slaking.

The highest results in the recovery of $\mathrm{B}_{2} \mathrm{O}_{3}$ (up to $98 \%$ ) were shown by fused colemanite. When using powdered colemanite, considerable dusting is noted when loading into the ladle and processing slag, associated with the removal of the dust-like fraction of material from the bowl with hot air streams. This is confirmed by the low recovery of $\mathrm{B}_{2} \mathrm{O}_{3}(63-64 \%)$.

The use of briquetted colemanite in the process of slags stabilization showed consistently good results. Samples taken from liquid slags showed an average recovery of $\mathrm{B}_{2} \mathrm{O}_{3}$ of $82.7 \%$. Slag samples taken after cooling and stabilization showed an average recovery of $\mathrm{B}_{2} \mathrm{O}_{3}$ of $76 \%$. It should be noted the low level of dust when using briquettes, similar to the process with fused colemanite. 
Thus, the principal possibility of the SRFC effective stabilization with various materials containing $\mathrm{B}_{2} \mathrm{O}_{3}$ was shown.

As a result of research and development on stabilization of self- slaking slags of ferroalloy production, by introducing boron-containing materials, a product was obtained that fully meets technical requirements TU 0798-69-00186499-2014 "Crushed stone and sand from ferroalloy slags. Technical conditions" based on tests of slag samples in the laboratory of LLC "Rosorgtekhstrom", Yekaterinburg. The slag manufacturer OJSC SZF was issued a Certificate of Conformity No. ROSS RU.Al16. N13144, No. 1474762.

According to the results of this work, calcined briquetted or fused colemanite is recommended for further use to stabilize slags.

\section{Funding}

The study was supported by a grant from the Russian Science Foundation (project No. 16-19-10435).

\section{References}

[1] Grabeliks, A.A., Demin, B.L., Kayrakbaev, S.N. (2010). New technologies of crystallochemical stabilization of slags from refined ferrochrome production. Stal', no. 5, pp. 78-83.

[2] Sheshukov, O.Yu., Mikheenkov, M.A., Nekrasov, I.V. et al. (2017). Utilization issues of steelmaking refining slags: monography. Nizhniy Tagil: NTI UrFU.

[3] Fadeev, V.I., Ostrovskiy, Ya.I., Bobkova, O.S. et al. Patent Rus no. 2424342 The method for obtaining low carbon ferrochrome; published 20.07.2011, Bulletin. no 20.

[4] Zayakin, O.V., Statnykh R.N., Zhuchkov, V.I. (2018). Studying the characteristics of slag melts in the production of low-carbon ferrochromium. Metallurg, no. 9, pp. 25-29.

[5] Ghose, A., Chopra, S., Young, J.F. (1983). Microstructural characterization of doped dicalcium silicate polymorphs. J. Mater. Sci, vol. 18, pp. 2905-2914.

[6] Beukes, J. P., Dawson, N. F., Van, Zyl P.G. (2010). Theoretical and practical aspects of $\mathrm{Cr}(\mathrm{VI})$ in the South African ferrochrome industry, in Proceedings of the Twelfth International Ferroalloys Congress. Sustainable Future. Helsinki, Finland.

[7] Akberdin, A.A., Kim, A.S., Esenjulov, A.B. et al. (2004). Introduction of stabilization technology from silicate decomposition of basic metallurgical slags. In Proceedings of int. Sci-peacticalconf. Theory and practice of pig iron production. Krivoy. rog.. pp. 295-297. 
[8] Zhuchkov, V. I., Zayakin O. V., Leont'ev L. I. (2008). Main Trends in the Processing of Poor Chrome Ore Raw Materials. Russian Metallurgy (Metally), no. 8., pp. 709-712.

[9] Kascheev, I.D., Zemlyanoy, K.G., Dosekenov, M.S. et al. (2012). The main characteristics of slags and dust generated during the production of ferrochrome. Proceedings of the congress "Fundamentals of technologies for processing and recycling of manmade waste. TECHNOGEN - 2012. Ekaterinburg: UIPC.

[10] Zhuchkov, V.I., Zayakin O.V., Zhdanov A.V. (2010). Utilization of substandard and offgrade raw materials for chromium and manganese ferroalloys production. Proceedings of the 12th International Ferroalloys Congress: Sustainable Future. Helsinki, Finland: Outotec Oyj.

[11] Karnouhov, V.N., Voronov, Yu.I., Zayko, V.P. et al. (2001). Low carbon ferrochrome technology. Ekaterinburg: UrO RAN.

[12] Akberdin, A.A. (1989). Calculation of the equilibrium phase composition of oxide systems. Izvestiya AN SSSR. Metally, no. 2, pp. 20-28.

[13] Zhuchkov, V.I., Akberdin, A.A., Vatolin N.A. (2011). Application of Boron-Containing Materials in Metallurgy. Russian Metallurgy, no. 12, pp. 1134-1137.

[14] Gin'e, A., Regur, M. (1973). Minerals structure. In Proceedings of the 5th International Cement Chemistry Congress. Moscow: Stroyizdat.

[15] Gorshkov, V.S., Alexandrov, S.E., Ivaschenko S.I., et al. (1985). Complex processing and use of metallurgical slag in construction. Moscow: stroiizdat.

[16] Akberdin, A.A., Ogurcov, E.A. (1998). Physical properties of boron-containing steel slags. Proceedings of the IX Int. scientific - tech. conf. "Theory and practice of oxygen-converter processes.». Dnepropetrovsk.

[17] Zayakin, O.V., Akberdin, A.A., Kim, A.S. et al. (2015). Study of the viscosity and crystallization temperature of ferrochrome slags. Proceedings of the XIV Russian Conf. "The structure and properties of metal and slag melts". Ekaterinburg: UrO RAN. 